\title{
Challenges to the Management of High-Risk Stroke Patients with Multiple-Site Occlusive Vascular Disease
}

\author{
Dirk Sander $^{\mathrm{a}, \mathrm{b}}$ Antonio Carolei ${ }^{\mathrm{e}}$ Curt Diehm ${ }^{c}$ Michael G. Hennerici ${ }^{\mathrm{d}}$ \\ Peter M. Rothwell ${ }^{f}$ \\ a Department of Neurology, Benedictus Hospital, Tutzing, bepartment of Neurology, University of Technology, \\ Munich, 'Department of Internal Medicine/Vascular Medicine, SRH-Klinikum Karlsbad-Langensteinbach, and \\ ${ }^{\mathrm{d} U n i v e r s i t y ~ o f ~ H e i d e l b e r g, ~ U n i v e r s i t a ̈ t s k l i n i k u m ~ M a n n h e i m, ~ M a n n h e i m, ~ G e r m a n y ; ~}{ }^{\mathrm{D}}$ Department of Neurology,

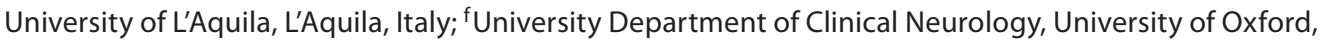 \\ John Radcliffe Hospital, Oxford, UK
}

\section{Key Words}

Stroke $\cdot$ Peripheral arterial disease $\cdot$ Coronary artery disease $\cdot$ Evidence-based practice

\begin{abstract}
Stroke patients are at high risk of secondary vascular events. Although in the short term the risk of experiencing a second stroke is high, in the long term patients are more likely to have myocardial infarction. Many stroke patients have also developed polyvascular disease in the form of coronary artery disease and peripheral arterial disease, which is a marker of increased morbidity and mortality in patients with non-cardioembolic ischemic stroke. Despite the high risk of events in these patients, current evidence-based guidelines make very few recommendations that address the need to detect and manage polyvascular disease following a stroke. Optimised Stroke Care for Re-Admission Reduction in Europe (OSCARE) is an initiative that has been set up to address some of these shortcomings.

Copyright $\odot 2011$ S. Karger AG, Basel
\end{abstract}

\section{Introduction}

Ischaemic stroke is associated with a significant burden to the patient, carers and health systems. Stroke is the second leading cause of death worldwide, with around 5.5 million deaths occurring in the 15 million people who have a stroke each year [1]. Approximately one third of stroke patients will be left permanently disabled, rendering stroke a leading cause of adult long-term disability. Hospital readmission due to a second cerebrovascular event is common with $20-27 \%$ of patients readmitted within the first year $[2,3]$. However, over 10 years, the risk of recurrent stroke decreases and other vascular events are more common [2-4]. Patients who have experienced an atherothrombotic stroke often have atherothrombotic disease in other arterial territories (polyvascular disease, polyVD), most often in the form of coronary artery disease (CAD) and/or peripheral arterial disease (PAD) [5]. Recent results have highlighted the importance of polyVD as a marker of increased morbidity and mortality in these patients [6-8]. Despite these data, polyVD is often inadequately assessed and stroke patients with polyVD are frequently not diagnosed, investigated or treated optimally [9].

\section{KARGER}

Fax +4161306 1234 E-Mail karger@karger.ch www.karger.com (c) 2011 S. Karger AG, Basel

1015-9770/11/0314-0315\$38.00/0

Accessible online at:

www.karger.com/ced
Dirk Sander

Department of Neurology, Benedictus Hospital Tutzing

Department of Neurology, University of Technology, Munich

Dr-Appelhans-Weg 6, DE-82340 Feldafing (Germany)

Tel. +49 8157 28140, Fax +498157 28141, E-Mail d.sander@mac.com 


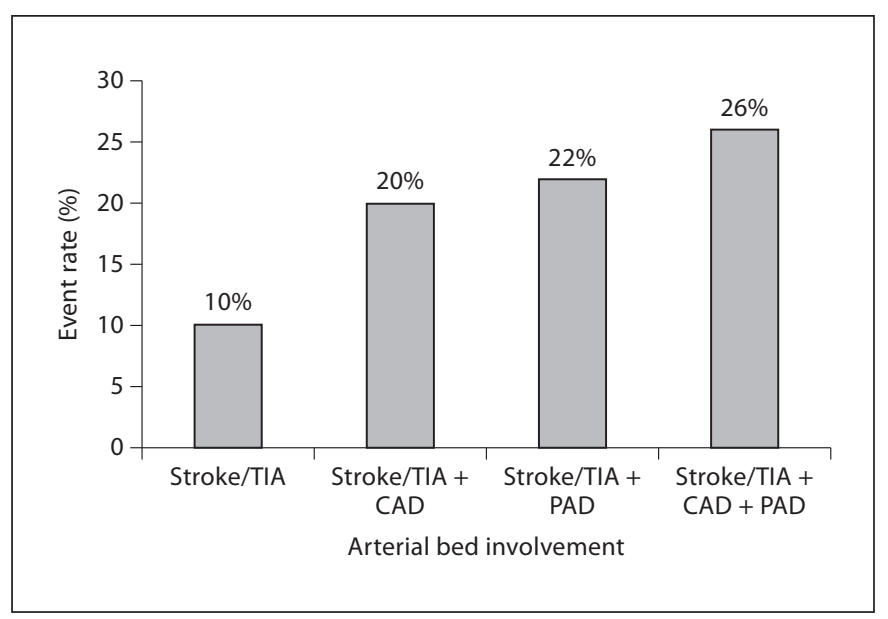

Fig. 1. One-year rates of $\mathrm{CV}$ death, MI, stroke or hospitalization in patients with cerebrovascular disease from the REACH registry [10].

The aim of this article is (1) to summarise the available data that stroke patients with polyVD have an increased morbidity and mortality, (2) to highlight unmet needs and areas where data are currently lacking, and (3) to introduce the Optimised Stroke Care for Re-Admission Reduction in Europe (OSCARE) initiative, designed to improve the care of high-risk stroke patients with polyVD

\section{Stroke Patients with polyVD: A High-Risk Population}

Table 1 summarises the evidence showing that poly$\mathrm{VD}$ is very common in patients with atherothrombotic stroke/transient ischaemic attack (TIA), and is associated with a high risk. The international Reduction of Atherothrombosis for Continued Health (REACH) registry of 67,888 patients with symptomatic atherothrombotic disease showed that $41 \%$ of patients with stroke/TIA $(18,843$ patients with predominantly non-cardiogenic ischaemic stroke) also had disease in at least one additional vascular territory $[5,10,11]$. Patients with documented polyVD have more than double the risk of a major event or hospitalisation at 1 year compared with patients in whom only the cerebral territory is involved (fig. 1) [12]. This was supported by a meta-analysis of 39 studies, involving 65,996 patients with stroke or TIA, where the 1-year rate of non-stroke vascular death was $2.1 \%$ and myocardial infarction (MI) was $2.2 \%$ [13]. The increased risk of recurrent stroke in patients with polyVD may in part be due to an increased variability in blood pressure in these patients, probably due to increased vascular stiffness, which in itself is an independent risk factor for stroke $[14,15]$. The Polyvascular Atherothrombosis Observational Study (PATHOS), Systematic Risk Evaluation in Ischaemic Stroke (SCALA) study and German Epidemiological Study of ABI (Get$\mathrm{ABI}$ ) showed that in patients with stroke/TIA, PAD (defined by the ankle-brachial index, $A B I \leq 0.9$ ) was also present in $33.5,51$ and $30.3 \%$ of cases, respectively [16]. PATHOS showed that the presence of PAD was associated with a 1.5-fold increased risk of adverse 1-year outcomes [17-19]; SCALA showed that the presence of PAD was associated with a 2-fold higher risk of recurrent stroke or cardiovascular death after 17.5 months [20]. It is important to note that asymptomatic PAD is much more common than symptomatic PAD [20], but is associated with a similar increase in risk $[8,21]$.

Seo et al. [16] showed that stroke/TIA increased the risk of CAD by 11-fold [2, 3], and Gongora-Rivera et al. [22] showed that CAD could be detected in $>70 \%$ of patients who had died of stroke [22]. Furthermore, approximately $40 \%$ of these cases were clinically silent $[8,16-21]$.

polyVD is also associated with high economic cost burdens for healthcare systems. The presence of PAD or CAD in addition to stroke or TIA doubles the 1-year costs associated with hospitalisation for cardiovascular reasons (MI, stroke) as determined by the 1-year follow-up data of patients from the USA enrolled in the REACH registry [23].

\section{What Is Missing from the Guidelines?}

Despite the high frequency of stroke patients with atherothrombotic disease in additional vascular territories, and the increased risk that is associated with polyVD, current treatment guidelines do not specifically address the management of polyVD in patients who have experienced a stroke. Current guidelines do provide targets for many of the risk factors for atherothrombosis (blood pressure, lipids and blood glucose, among others). However, no routine screening for polyVD is recommended, and polyVD is, therefore, likely to frequently go undetected. In addition to its detection, no specific recommendations are made in the current guidelines for the long-term treatment and management of stroke patients with polyVD. One of the main reasons for this gap in the guidelines is the lack of evidence available in patients with stroke associated with polyVD [24]. 
Table 1. Summary of polyVD studies

\begin{tabular}{|c|c|c|c|}
\hline Study & Design & Patients & Key findings \\
\hline $\begin{array}{l}\text { REACH } \\
\text { (Bhatt et al., } \\
\text { 2006; Steg et al., } \\
\text { 2007) }[5,6,10]\end{array}$ & Registry & $\begin{array}{l}67,888 \text { patients with symptomatic } \\
\text { atherothrombotic disease, including } \\
18,843 \text { patients with stroke or TIA } \\
\text { (predominantly non-cardiogenic } \\
\text { atherothrombotic disease) }\end{array}$ & $\begin{array}{l}\text { polyVD is very common and carries an increased risk } \\
30 \% \text { of stroke/TIA patients also had CAD; } 5 \% \text { also had PAD; } 6 \% \text { also had both CAD } \\
\text { and PAD } \\
\text { Polyvascular stroke/TIA more than doubles the risk of a major event or hospitalization } \\
\text { at } 1 \text { year compared with monovascular stroke/TIA } \\
22 \% \text { of patients with stroke/TIA + PAD experienced MI, cardiovascular death and } \\
\text { stroke, or hospitalization within } 1 \text { year } \\
20 \% \text { of patients with stroke/TIA + CAD experienced a major cardiovascular event with- } \\
\text { in } 1 \text { year } \\
\text { In patients with carotid artery stenosis }{ }^{1} \text {, cardiovascular death, myocardial infarction or } \\
\text { stroke was seen in } 6.03 \% \text { after } 1 \text { year (vs. } 4.29 \% \text { for patients without carotid artery ste- } \\
\text { nosis) }\end{array}$ \\
\hline
\end{tabular}

\begin{tabular}{lll}
\hline Touze et al., & Meta- & 65,996 patients with stroke or TIA, \\
$2005[13]$ & analysis & pooled from 39 studies
\end{tabular}

Atherothrombotic stroke is associated with events in other vascular territories

1-year rate of non-stroke vascular death was 2.1\% (95\% CI 1.9-2.4) and MI was 2.2\% (95\% CI 1.7-2.7)

In studies specifically examining patients with TIA or stroke attributable to atherosclerosis, the risk of MI (4 studies) was $1.9 \%$ per year (95\% CI, not estimable) and that of nonstroke vascular death (5 studies) was $2.3 \%$ per year (95\% CI 1.9-2.7)

\begin{tabular}{|c|c|c|c|}
\hline $\begin{array}{l}\text { Touze et al., } \\
2006[34]\end{array}$ & $\begin{array}{l}\text { Prospective } \\
\text { review of } \\
\text { angio- } \\
\text { grams }\end{array}$ & $\begin{array}{l}2,741 \text { patients with a recently } \\
\text { symptomatic carotid stenosis } \\
\text { (unilateral vs bilateral) }\end{array}$ & $\begin{array}{l}\text { Bilateral carotid stenosis }{ }^{2} \text { (due to atherosclerosis) is suggestive of generalized athero- } \\
\text { sclerotic disease, and is associated with increased event rates in other vascular territo- } \\
\text { ries } \\
\text { Non-stroke-related vascular death has been shown to be associated with bilateral ca- } \\
\text { rotid artery disease (hazard ratio } 2.0 ; 95 \% \text { CI } 1.5-2.6 \text { ), again reflecting systemic disease }\end{array}$ \\
\hline $\begin{array}{l}\text { Seo et al., } \\
2008[16]\end{array}$ & $\begin{array}{l}\text { Observa- } \\
\text { tional } \\
\text { study }\end{array}$ & $\begin{array}{l}71 \text { patients with ischaemic stroke. } \\
\text { CAD identified using CT coronary } \\
\text { angiography }\end{array}$ & $\begin{array}{l}\text { CAD is very common in patients with atherothrombotic stroke/TIA } \\
25.4 \% \text { of patients had significant CAD, and this was associated with the presence of ath- } \\
\text { erosclerosis of the carotid artery. This represents an } 11 \text {-fold increased risk of CAD com- } \\
\text { pared with an age-matched control population }\end{array}$ \\
\hline $\begin{array}{l}\text { Gongora- } \\
\text { Rivera et al., } \\
2007[22]\end{array}$ & $\begin{array}{l}\text { Autopsy } \\
\text { study }\end{array}$ & $\begin{array}{l}803 \text { consecutive autopsies of } \\
\text { neurologic patients; } 341 \text { had stroke; } \\
251 \text { had brain infarction; } \\
\text { and } 60 \text { had confirmed athero- } \\
\text { thrombotic stroke }\end{array}$ & $\begin{array}{l}\text { Comorbid CAD is common and often asymptomatic } \\
\text { Coronary artery plaques were found in } 78.3 \% \text { of cases with atherothrombotic stroke } \\
\text { MI was evident in } 36.7 \% \text { of cases with atherothrombotic stroke } \\
\text { In the overall cohort, around } 2 / 3 \text { of cases of MI were clinically silent }\end{array}$ \\
\hline $\begin{array}{l}\text { PATHOS } \\
\text { (Agnelli et al., } \\
\text { 2006) [35] }\end{array}$ & $\begin{array}{l}\text { Observa- } \\
\text { tional } \\
\text { study }\end{array}$ & $\begin{array}{l}755 \text { patients hospitalized for acute } \\
\text { stroke or TIA (aetiology unspecified) }\end{array}$ & $\begin{array}{l}\text { PAD is common and associated with worse outcomes in patients with stroke or TIA } \\
\mathrm{ABI} \leq 0.9 \text { was found in } 33.5 \% \text { of patients } \\
\mathrm{ABI} \leq 0.9 \text { was associated with a } 1.5 \text {-fold increased risk of adverse } 1 \text {-year outcomes }\end{array}$ \\
\hline $\begin{array}{l}\text { Busch et al., } \\
2009 \text { [7] }\end{array}$ & $\begin{array}{l}\text { Observa- } \\
\text { tional } \\
\text { study }\end{array}$ & $\begin{array}{l}204 \text { patients with acute ischaemic } \\
\text { stroke or TIA followed for a mean of } \\
2.3 \text { years; included } 46 \text { cases with a } \\
\text { confirmed atherosclerotic aetiology }\end{array}$ & $\begin{array}{l}\text { PAD is associated with worse outcomes in patients with stroke or TIA } \\
\text { In the overall cohort, } \mathrm{ABI} \leq 0.9 \text { at baseline was associated with a significantly higher rate } \\
\text { of stroke, } \mathrm{MI} \text { or death }(12.8 \text { vs. } 6.4 \% ; \mathrm{p}=0.03)\end{array}$ \\
\hline $\begin{array}{l}\text { SCALA } \\
\text { (Weimar et al., } \\
\text { 2007; } \\
\text { Weimar et al., } \\
2008)[20,36]\end{array}$ & $\begin{array}{l}\text { Observa- } \\
\text { tional } \\
\text { study }\end{array}$ & $\begin{array}{l}852 \text { patients hospitalized for } \\
\text { ischaemic stroke or TIA from } 85 \\
\text { stroke units across Germany. } \\
\text { Did not exclude non-atherosclerotic } \\
\text { aetiology }\end{array}$ & $\begin{array}{l}\text { Asymptomatic PAD is much more common than symptomatic PAD } \\
51 \% \text { of patients had an } \mathrm{ABI} \leq 0.9 \\
\text { Only } 10 \% \text { had classic } \mathrm{PAD} \text { symptoms, such as intermittent claudication or signs of } \\
\text { critical limb ischaemia } \\
\text { PAD (symptomatic and asymptomatic) is associated with worse outcomes in patients } \\
\text { with stroke or TIA } \\
\text { After } 17.5 \text { months, a } 2 \text {-fold higher risk of recurrent stroke or cardiovascular death was } \\
\text { reported in patients that had experienced a stroke or TIA with an ABI } \leq 0.9 \text { compared } \\
\text { with patients with an } \mathrm{ABI}>0.9\end{array}$ \\
\hline $\begin{array}{l}\text { GetABI } \\
\text { (Diehm et al., } \\
\text { 2009) [8] }\end{array}$ & $\begin{array}{l}\text { Epidemio- } \\
\text { logical } \\
\text { study }\end{array}$ & $\begin{array}{l}6,880 \text { unselected patients ( } \geq 65 \text { years) } \\
\text { from primary care }\end{array}$ & $\begin{array}{l}\text { Asymptomatic PAD is common in an unselected primary care population } \\
\text { ABI } \leq 0.9 \text { was found in } 30.3 \% \text { of patients with cerebrovascular disease }(n=607) \\
\text { Asymptomatic PAD has a similar comorbidity and risk-factor profile to symptomatic } \\
\text { PAD } \\
5 \text {-year all-cause mortality risk was not significantly different between asymptomatic and } \\
\text { symptomatic PAD patients }\end{array}$ \\
\hline
\end{tabular}

\footnotetext{
${ }^{1}$ Asymptomatic carotid artery stenosis, diagnosed by colour-coded duplex sonography or digital subtraction angiography demonstrating $\geq 70 \%$ steno-
} sis. ${ }^{2}$ Measured using the European Carotid Surgery Trial method. 
The difficulties associated with the post-discharge care of high-risk polyVD patients are not adequately addressed in the current guidelines. Specifically, the guidelines do not address practical issues such as the lack of information for patients regarding the benefits and services available, as well as detailed explanations about their condition [25]. In a 2-year follow-up study of patients admitted to hospital in New Zealand following an acute stroke, patients still had questions about their condition at both 6 and 24 months after admission [26]. Importantly, the type of information that they required changed over this 2 -year time period, with questions on the basic aspects of stroke decreasing over 2 years and questions on the psychological impact of stroke increasing. Providing patients with booklets only is not sufficient to improve patient satisfaction and will not necessarily improve the care perceived by patients [27].

Following discharge from hospital, patients are recommended to adhere to guideline therapy for the secondary prevention of cardiovascular events. However, patient adherence is often not optimal. For example, a study of antihypertensive drugs used to control cardiovascular risk factors in elderly patients with grade I or II hypertension found that only $34 \%$ of patients fully adhered to their prescribed diuretics after 24 months [28]. In fact, adherence to any cardiovascular drug following an acute MI, has recently been shown to be low in patients discharged from hospital with as few as $44 \%$ of patients adhering to their recommended treatment with clopidogrel [29]. Despite these results, patients' adherence to therapies can be improved by relatively simple interventions, as shown in studies of patients with atherothrombotic disease [30,31]. A visit to the cardiologist or primary care physician by the patient less than 1 month after discharge after acute MI, for example, is associated with higher rates of evidence-based medication use [30]. Furthermore, improved communication between the physician and patient was shown to increase patient compliance with $\beta$-blocker after acute MI [31].

\section{The OSCARE Initiative}

Currently, there is no standardised care protocol addressing the optimised treatment and management of patients with stroke and polyVD. There is need for protocols focussing on:

- Screening for polyVD

- Optimised treatment and discharge for stroke patients with polyVD

- Transfer of care for long-term follow-up
OSCARE is an initiative that has been set up to address some of the challenges associated with the care of all high-risk patients receiving inpatient hospital treatment for acute and recent ischaemic stroke, with particular focus on the management and treatment of high-risk stroke patients with polyVD. The aims of OSCARE are to continue the optimal treatment following discharge, to increase the adherence of the patients and to optimise risk factor control.

The OSCARE initiative will be evaluated in a singlecentre pilot study with consecutive non-cardioembolic stroke patients with polyVD receiving the OSCARE approach $(n=100)$ or a usual-care approach $(n=100)$. Follow-up will be 1 year. One important aim of OSCARE is to identify the highest risk patients for a new vascular event. Patients will be screened for standard risk factors (such as arterial hypertension, diabetes, lipids, and smoking habit, among others), cardiovascular disease (ECG, patient history), peripheral arterial disease (ABI measurement) and carotid disease (through determination of intima-media thickness). Patients will be included in the study if they had a symptomatic or asymptomatic vascular disease in at least one other vascular bed (coronary or peripheral). Patients from the OSCARE group will receive a standardised transfer of care document including patient information that summarises the findings of the screening for polyVD, highlights the increased risk of these patients and underscores the importance of an optimised treatment. In addition, these patients will receive regular reviews every 3 months by a specifically trained vascular nurse. During the review, the following points will be addressed:

- Adherence to medication

- Risk factor control (revised personal risk factor documents)

- Quality of life

- Blood pressure (3 measurements over a 30-min period)

- What can be done to improve adherence to treatment?

- Regular follow-up appointments

- Patient education

After the follow-up, the OSCARE approach was compared to the usual-care approach with regard to medication adherence, risk factor control (blood pressure, diabetes, hyperlipidemia, smoking; primary endpoints) and occurrence of new vascular events defined as a composite of MI, stroke and vascular death (secondary endpoint). It is hypothesised that the OSCARE group shows a significantly $(\mathrm{p}<0.05)$ improved medication adherence and risk factor control as well as a lower rate of new vascular events. 
Table 2. Discharge documentation for stroke patients with polyVD

\begin{tabular}{|c|c|}
\hline Document & Information included \\
\hline $\begin{array}{l}\text { Letter to primary care } \\
\text { physician }\end{array}$ & $\begin{array}{l}\text { Description of discharge materials } \\
\text { Standard form from the specialist containing information such as diagnosis, lifestyle advice, follow-up } \\
\text { appointments specific for the patient }\end{array}$ \\
\hline Transfer of care & $\begin{array}{l}\text { History of vascular events } \\
\text { Medication history } \\
\text { List of diagnostic tests carried out during hospital stay } \\
\text { Blood pressure measurements } \\
\text { Lipid measurements } \\
\text { Liver function test measurements } \\
\text { ECG report } \\
\text { Smoking history } \\
\text { Alcohol intake } \\
\text { Identification of other risk factors for stroke } \\
\text { Results of ECG, carotid Doppler, brain MRI and CT scan (including details of final diagnosis and } \\
\text { stroke type) } \\
\text { Results of screening for polyVD (including cardiovascular investigations, ABI measurements) } \\
\text { Recommendation for carotid endarterectomy where appropriate } \\
\text { Secondary prevention strategy (including rationale for managing high-risk patients) } \\
\text { Details of discharge medication (including intended duration of therapy) } \\
\text { Details of changes to medication and rationale for these changes } \\
\text { Recommendation for long-term follow-up }\end{array}$ \\
\hline $\begin{array}{l}\text { Transfer of care medication } \\
\text { document }\end{array}$ & $\begin{array}{l}\text { Medications prescribed to the patient within hospital care } \\
\text { Contain space for primary care physicians to detail when and why medications are altered post- } \\
\text { discharge }\end{array}$ \\
\hline $\begin{array}{l}\text { Patient information pack, } \\
\text { tailored to the individual } \\
\text { needs of the patient }\end{array}$ & $\begin{array}{l}\text { What you should know about PAD } \\
\text { Stroke and PAD (patient information booklet) } \\
\text { Stroke warning card } \\
\text { Stroke and PAD passport } \\
\text { Patient progress diary } \\
\text { 'Looking after yourself after you have had a stroke' patient leaflet providing medication details and } \\
\text { importance of medication adherence }\end{array}$ \\
\hline Physician information pack & Slide kit and booklet describing slides \\
\hline Other information & $\begin{array}{l}\text { ABI measurement calculator } \\
\text { Assessment of risk for further ischaemic events and PAD } \\
\text { Follow-up questionnaire }\end{array}$ \\
\hline
\end{tabular}

\section{Development of Materials}

As part of the initiative to improve the care available for patients who have experienced a stroke, OSCARE is developing a range of web-based materials to assist in the transfer of patients from hospital to community care. These materials will also help to support the long-term care of patients in the community. Transfer should ensure the smooth continuation of optimal therapy, to increase both the quality of life and satisfaction of patients. Discharge of patients from hospitals must, therefore, be completed in a way that is well planned to ensure maximum satisfaction from both patients and carers, and in a way that encourages communication between healthcare professionals, carers and patients [32, 33].

Materials under development by OSCARE to aid the switch from hospital to community care include transfer of care documentation, patient information and support documents (table 2). The transfer of care documentation prepared before discharge from hospital for each patient could help to ensure that the transfer of patient care from hospital to community care occurs in an optimal and effective manner.

The discharge materials being developed by OSCARE aim to help in the delivery of continued optimal care for 
high-risk stroke patients by keeping all relevant stakeholders fully informed of the medical history and treatment of each patient, and ensuring that all details provided are comprehensive and up to date. Consequently, it is hoped that this initiative will improve physician and patient adherence to optimal therapy and that it will help support an integrated multidisciplinary approach to care in the community.

\section{Conclusions}

Stroke patients with polyVD are at an increased risk of secondary cardiovascular events, which can lead to high hospital readmission rates. Although there is evidence that suggests there is a high prevalence of polyVD in patients who have experienced a stroke, polyVD is often not detected, potentially resulting in suboptimal management of the disease. Despite the clinical need to manage high-risk stroke patients more effectively, current evi- dence-based guidelines do not adequately address the detection and treatment of polyVD in stroke patients. These issues must therefore be addressed to provide patients with the best possible treatment. OSCARE is an initiative set up to reduce these shortcomings, and aims to increase the awareness and promote the investigation of potential polyVD in stroke patients. By highlighting the full extent of the risks associated with this high-risk population, OSCARE aims to provide the optimum care for stroke patients with polyVD.

\section{Acknowledgements}

The authors would like to thank Fiona Murray-Zmijewski of Wolters Kluwer Health for her editorial support, supported by Bristol-Myers Squibb.

OSCARE steering committee: Pierre Amarenco, Antonio Carolei, Curt Diehm, Michael Hennerici, Peter Rothwell, Dirk Sander, Philippe Gabriel Steg.

\section{References}

1 Mackay J, Mensah G: The Atlas of Heart Disease and Stroke. Geneva, WHO, 2004.

-2 Thorngren M, Westling B, Norrving B: Outcome after stroke in patients discharged to independent living. Stroke 1990;21:236240.

- 3 Sacco RL, Hauser WA, Mohr JP: Hospitalized stroke in Blacks and Hispanics in Northern Manhattan. Stroke 1991;22:14911496.

4 Pendlebury ST, Rothwell PM: Risk of recurrent stroke, other vascular events and dementia after transient ischaemic attack and stroke. Cerebrovasc Dis 2009;27(suppl 3):111.

-5 Bhatt DL, Steg PG, Ohman EM, Hirsch AT, Ikeda Y, Mas JL, Goto S, Liau CS, Richard AJ, Rother J, Wilson PW: International prevalence, recognition, and treatment of cardiovascular risk factors in outpatients with atherothrombosis. JAMA 2006;295:180189.

-6 Aichner FT, Topakian R, Alberts MJ, Bhatt DL, Haring HP, Hill MD, Montalescot G, Goto S, Touze E, Mas JL, Steg PG, Rother J: High cardiovascular event rates in patients with asymptomatic carotid stenosis: The REACH Registry. Eur J Neurol 2009; 16:902908.

7 Busch MA, Lutz K, Rohl JE, Neuner B, Masuhr F: Low ankle-brachial index predicts cardiovascular risk after acute ischemic stroke or transient ischemic attack. Stroke 2009;40:3700-3705.
-8 Diehm C, Allenberg JR, Pittrow D, Mahn M, Tepohl G, Haberl RL, Darius H, Burghaus I, Trampisch HJ: Mortality and vascular morbidity in older adults with asymptomatic versus symptomatic peripheral artery disease. Circulation 2009;120:2053-2061.

-9 Carolei A, Chamorro A, Laloux P, Leys D, Rother J, Sander D, Stansby G, Weimar C: Identification and management of polyvascular disease in patients with noncardioembolic ischaemic stroke. Int J Stroke 2008;3: 237-248.

10 Steg PG, Bhatt DL, Wilson PW, D'Agostino R Sr, Ohman EM, Rother J, Liau CS, Hirsch AT, Mas JL, Ikeda Y, Pencina MJ, Goto S: One-year cardiovascular event rates in outpatients with atherothrombosis. JAMA 2007;297:1197-1206.

11 Mostaza JM, Martin-Jadraque R, Vicente I, San Martin MA, Lahoz C: Patients at high risk of cerebrovascular disease: the REACH study. Cerebrovasc Dis 2009;27(suppl 1):7781. 12 Rothwell PM, Coull AJ, Giles MF, Howard
SC, Silver LE, Bull LM, Gutnikov SA, Edwards P, Mant D, Sackley CM, Farmer A, Sandercock PA, Dennis MS, Warlow CP, Bamford JM, Anslow P: Change in stroke incidence, mortality, case-fatality, severity, and risk factors in Oxfordshire, UK from 1981 to 2004 (Oxford Vascular Study). Lancet 2004;363:1925-1933.
13 Touze E, Varenne O, Chatellier G, Peyrard S, Rothwell PM, Mas JL: Risk of myocardial infarction and vascular death after transient ischemic attack and ischemic stroke: a systematic review and meta-analysis. Stroke 2005;36:2748-2755.

14 Howard SC, Rothwell PM: Reproducibility of measures of visit-to-visit variability in blood pressure after transient ischaemic attack or minor stroke. Cerebrovasc Dis 2009; 28:331-340.

15 Rothwell PM, Howard SC, Dolan E, O’Brien E, Dobson JE, Dahlof B, Sever PS, Poulter NR: Prognostic significance of visit-to-visit variability, maximum systolic blood pressure, and episodic hypertension. Lancet 2010;375:895-905.

-16 Seo WK, Yong HS, Koh SB, Suh SI, Kim JH, Yu SW, Lee JY: Correlation of coronary artery atherosclerosis with atherosclerosis of the intracranial cerebral artery and the extracranial carotid artery. Eur Neurol 2008; 59:292-298.

17 Weitz JI, Byrne J, Clagett GP, Farkouh ME, Porter JM, Sackett DL, Strandness DE Jr, Taylor LM: Diagnosis and treatment of chronic arterial insufficiency of the lower extremities: a critical review. Circulation 1996;94:3026-3049.

18 Meijer WT, Hoes AW, Rutgers D, Bots ML, Hofman A, Grobbee DE: Peripheral arterial disease in the elderly: the Rotterdam study. Arterioscler Thromb Vasc Biol 1998;18:185192. 
19 Belch JJ, Topol EJ, Agnelli G, Bertrand M, Califf RM, Clement DL, Creager MA, Easton JD, Gavin JR 3rd, Greenland P, Hankey G, Hanrath P, Hirsch AT, Meyer J, Smith SC, Sullivan F, Weber MA: Critical issues in peripheral arterial disease detection and management: a call to action. Arch Intern Med 2003;163:884-892.

-20 Weimar C, Goertler M, Rother J, Ringelstein EB, Darius H, Nabavi DG, Kim IH, Theobald K, Diener HC: Systemic Risk Score Evaluation in Ischemic Stroke Patients (SCALA): a prospective cross sectional study in 85 German stroke units. J Neurol 2007;254:15621568.

21 Meves SH, Diehm C, Berger K, Pittrow D, Trampisch HJ, Burghaus I, Tepohl G, Allenberg JR, Endres HG, Schwertfeger M, Darius H, Haberl RL: Peripheral arterial disease as an independent predictor for excess stroke morbidity and mortality in primary-care patients: 5-year results of the getABI study. Cerebrovasc Dis 2010;29:546-554.

22 Gongora-Rivera F, Labreuche J, Jaramillo A, Steg PG, Hauw JJ, Amarenco P: Autopsy prevalence of coronary atherosclerosis in patients with fatal stroke. Stroke 2007;38:12031210.

23 Mahoney EM, Wang K, Cohen DJ, Hirsch AT, Alberts MJ, Eagle K, Mosse F, Jackson JD, Steg PG, Bhatt DL: One-year costs in patients with a history of or at risk for atherothrombosis in the united states. Circ Cardiovasc Qual Outcomes 2008;1:38-45.
24 European Stroke Organisation: Guidelines for management of ischaemic stroke and transient ischaemic attack 2008. Cerebrovasc Dis 2008;25:457-507.

25 Greveson G, James O: Improving long-term outcome after stroke - the views of patients and carers. Health Trends 1991;23:161-162.

-26 Hanger HC, Walker G, Paterson LA, McBride S, Sainsbury R: What do patients and their carers want to know about stroke? A two-year follow-up study. Clin Rehabil 1998; 12:45-52.

27 Ayana M, Pound P, Lampe F, Ebrahim S: Improving stroke patients' care: a patient held record is not enough. BMC Health Serv Res 2001;1:1.

28 Borghi C, Veronesi M, Dormi A, Prandin MG, Cosentino E, Strocchi E: Persistence of treatment and blood pressure control in elderly hypertensive patients treated with different classes of antihypertensive drugs. Am J Geriatr Cardiol 2007;16:280-286.

29 Jackevicius CA, Li P, Tu JV: Prevalence, predictors, and outcomes of primary nonadherence after acute myocardial infarction. Circulation 2008;117:1028-1036.

-30 Daugherty SL, Ho PM, Spertus JA, Jones PG, Bach RG, Krumholz HM, Peterson ED, Rumsfeld JS, Masoudi FA: Association of early follow-up after acute myocardial infarction with higher rates of medication use. Arch Intern Med 2008;168:485-491; discussion 492.

- 31 Smith DH, Kramer JM, Perrin N, Platt R, Roblin DW, Lane K, Goodman M, Nelson WW, Yang X, Soumerai SB: A randomized trial of direct-to-patient communication to enhance adherence to $\beta$-blocker therapy following myocardial infarction. Arch Intern Med 2008;168:477-483; discussion 483; quiz 447.
32 Preen DB, Bailey BE, Wright A, Kendall P, Phillips M, Hung J, Hendriks R, Mather A, Williams E: Effects of a multidisciplinary, post-discharge continuance of care intervention on quality of life, discharge satisfaction, and hospital length of stay: a randomized controlled trial. Int J Qual Health Care 2005; 17:43-51.

33 Smith J, Forster A, House A, Knapp P, Wright J, Young J: Information provision for stroke patients and their caregivers. Cochrane Database Syst Rev 2008:CD001919.

34 Touze E, Warlow CP, Rothwell PM: Risk of coronary and other nonstroke vascular death in relation to the presence and extent of atherosclerotic disease at the carotid bifurcation. Stroke 2006;37:2904-2909.

35 Agnelli G, Cimminiello C, Meneghetti G, Urbinati S: Low ankle-brachial index predicts an adverse 1-year outcome after acute coronary and cerebrovascular events. J Thromb Haemost 2006;4:2599-2606.

36 Weimar C, Goertler M, Rother J, Ringelstein EB, Darius H, Nabavi DG, Kim IH, Benemann J, Diener HC: Predictive value of the Essen Stroke Risk Score and Ankle Brachial Index in acute ischaemic stroke patients from 85 German stroke units. J Neurol Neurosurg Psychiatry 2008;79:1339-1343. 